\title{
Response of Barley (Hordeum vulgare L.) Plants to Foliar Fertilizer with Different Concentrations of Hoagland Solution
}

\author{
*Mohammed Q. Khursheed \\ Zhian R. Salih \\ Trefa Z. Saber \\ Department of Biology/College of Education/University of Salahaddin/Erbil \\ *Email: dmohamad1677@gmail.com
}

(Received 20 / 1 /2014 ; Accepted 7/4 / 2014)

\begin{abstract}
This experiment was conducted in pots with a randomized complete design to study the effects of foliar application with Hoagland's solution (0, 1/4, 1/2, 3/4 and full strength) on some morphological, physiological and yield characters of barley cv. Towetha. Both 1/4 and 1/2 strength treatments showed significant increase in all morphological (height of plant, leaves number, flag leaf area, tiller numbers, shoot dry weight), physiological (chlorophyll a, b and total chlorophyll, total nitrogen and total protein) and yield characters (number of spikes/plant, 100-grains weight and grain yield/plant ) compared with the control treatment. It is concluded that barley cultivar gave a clear response to foliar application with Hoagland's solution and the half-strength Hoagland's solution was the preferred nutrient solution evaluated in this research.
\end{abstract}

Keywords: Hordeum vulgare, Foliar application, Hoagland's solution, Barley.

\section{استجابة محصول الثعير (Hordeum vulgare L) الى التسميد الورقي بمحلول هوكلاند بتراكيز مختلفة}

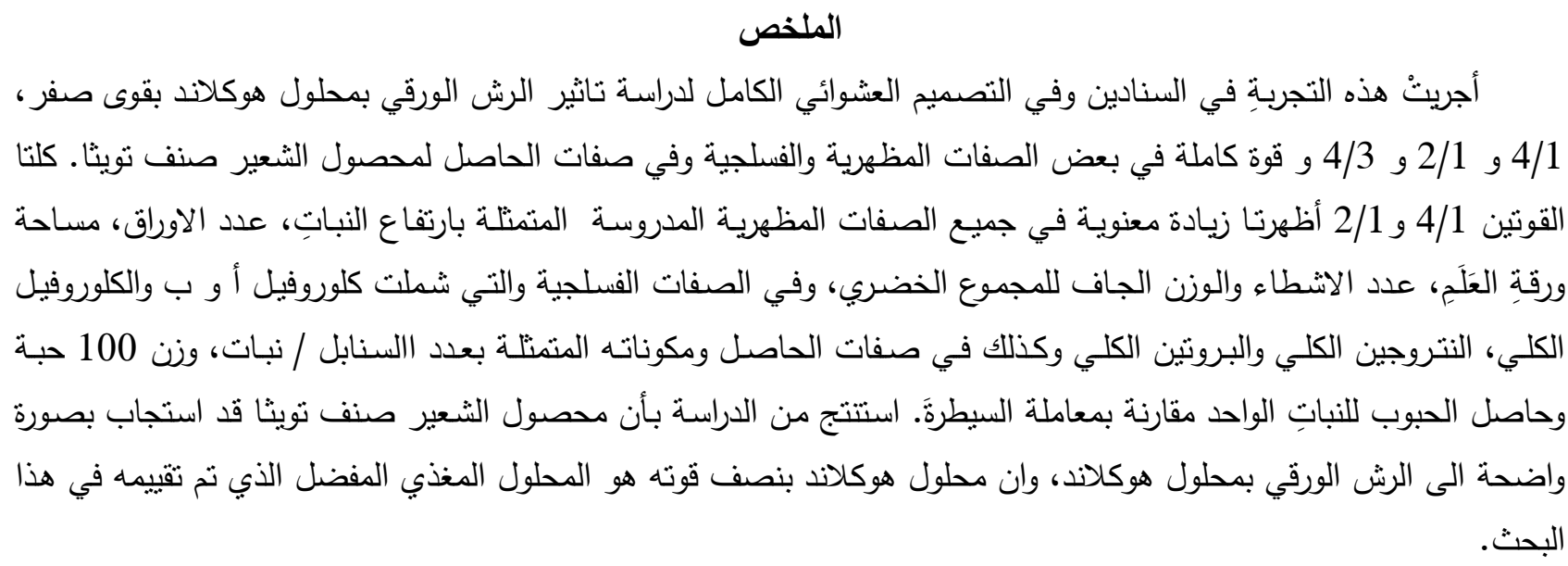

\section{INTRODUCTION}

Barley (Hordeum vulgare L.) from Gramineae (Poaceae) family is grown as a commercial crop in many developing countries, is assumes the fourth position in total cereal production in the world after wheat, rice, and maize (Naghaii and Asgharipour, 2011). Barley is considered the very important and necessary cereal crops for the life of the world societies especially Iraq. It is strategic crop planted in relatively large areas and its output is related to food security of almost all the developing countries including Iraq. In addition, barley is playing important role of international trade, where the world reports are indicated that food shortages are basically attributed to the lack of 
wheat and barely production. In Iraq, the total arable land is about 48 million donum, while only about 23 million donum is exploited (48\%). About $47 \%$ of the total exploited arable land is planted by the two cereal crops: wheat and barley (Al-Obaidy, 2012).

Plant nutrition is one of the most important factor that increases plant production. Mineral nutrition alone has contributed significantly to increase crop yields during the 20th century, 50\% of the increase in crop yields worldwide during the 20th century was due to application of chemical fertilizers. They also stated that during the 21 st century, the essential plant nutrients would be the single most important factor limiting crop yields, especially in developing countries. A balanced fertilization program with macro and micronutrients in plant nutrition is very important in the production of high yield with high quality products (Sawan et al., 2001). In most regions of the world the use of chemical fertilizers is very unbalanced and is not based on plants requirement. Each element in proper plant nutrition should be available enough for plants, and balance and respect the ratio between used nutrients is also important (Alloway, 2008). Qualitative and quantitative plant products can only be achieved if they are combined with proper plant nutrition. Besides the three macro elements (N, P, and $\mathrm{K}$ ) essential microelements are inevitable. Micronutrient deficiency is widespread in many Asian countries due to the calcareous nature of soils, high $\mathrm{pH}$, low organic matter, salt stress, continuous drought, high bicarbonate content in irrigation water, and imbalanced application of NPK fertilizers (Ahmadikhah et al., 2010). During the last decades, foliar fertilization of nutrients has become an established procedure to increase yield and improve the quality of crop products (Fageria et al., 2009). This procedure can also improve nutrient utilization and lower environmental pollution through reducing the amount of fertilizers added to soil (Abou El-Nour, 2002). On the other hand, foliar feeding of a nutrient not only an addition channel of nutrients but also a mean of regulating roots absorption by such plants (Ahmad et al., 2006).

The present study was undertaken to investigate the response of barley cultivar Towetha to foliar application with different levels of Hoagland solution.

\section{MATERIALS AND METHODS}

Greenhouse experiment was carried out in College of Education, University of Salahaddin Erbil during the period from December 15, 2011 to April 30, 2012. The soils were air-dried, grounded and passed through a 2-mm sieve. The soil portions were uniformly packed in plastic pots of 30-cm diameter and 30-cm height at a rate of $8 \mathrm{~kg}$ soil per pot. Physical and chemical properties of the used soils are shown in Table (1). The pots were brought to field capacity prior to sowing the seeds. Soil moisture status was maintained by frequently weighing the pots, and the amount of water equal to the weight loss was added. Six seeds of Barley (Hordeum vulgare L.) cv. Towetha were sown in each pot. One week after planting, seedlings were thinned to two vigorously growing plants per pot. All pots received $75 \mathrm{mg} \mathrm{P} / \mathrm{kg}$ soil, $75 \mathrm{mg} \mathrm{K} / \mathrm{kg}$ soil (as $\left(\mathrm{KH}_{2} \mathrm{PO}_{4}\right.$ containing $22.70 \% \mathrm{P}$ and $\% 28.60 \mathrm{~K}$ ). and $75 \mathrm{mg} \mathrm{N} / \mathrm{kg}$ soil $\left(\right.$ as $\left.\mathrm{NH}_{4} \mathrm{NO}_{3}, 33.5 \% \mathrm{~N}\right)$. Application of $\mathrm{K}$ and $\mathrm{P}$ fertilizer were done in a form of water solution added in the first irrigation. Nitrogen fertilizer was added in three equal doses, at $1 \mathrm{st}, 4^{\text {th }}$ and within the $9^{\text {th }}$ irrigation, respectively. Irrigation intervals were 4 days to maintain the soil moisture content at the field capacity by frequently weighing the pots, and the amount of water equal to the weight loss was added.

Water solutions of Hoagland plus surfactant [Tween 20 (Polyoxyethylene Sorbitan Monolaurate), $10 \mathrm{ml} \mathrm{1}^{-1}$ )] were prepared (Table 2), then seedlings were sprayed twice after 40 and 50days from sowing (at tillering stage). Foliar treatments were: (i) distilled water (ii) $1 / 4$ strength Hoagland's solution (iii) $1 / 2$ strength Hoagland's solution (iv) 3/4 strength Hoagland's solution and, (v) full strength Hoagland's solution. Hoagland's solution of 1/4, 1/2 and 3/4 strengths were prepared from full strength Hoagland's solution by dilution. The plants were sprayed with solutions at the early morning hours by small handed-sprayer that the control plants were sprayed with 
distilled water and the volume of the spray solution has to cover the plant foliage completely till drip. During spraying, each pot was surrounded by a portable wood barrier to prevent solution drift into adjacent pot. The experimental design was laid out in a randomized complete design with four replications.

The plant height, number of tillers and leaves, flag leaf area, shoot dry weight, leaf chlorophylls, total nitrogen and crude proteins were measured after 100days from sowing. The flag leaf area was measured by Stickler's equation (Stickler et al., 1961) as given below:

Leaf area $\left(\mathrm{cm}^{2}\right)=\mathrm{L} \times \mathrm{B} \times 0.747$

Where, $\mathrm{L}=$ length of leaf, $\mathrm{B}=$ Breadth of leaf

The chlorophylls $a$ and $b$ were determined according to the method of Arnon (1949), and calculated by the following formulae:

Chl $a=[12.7$ (OD 663) $-2.69(\mathrm{OD} 645)] \times \mathrm{V} / 1000 \times \mathrm{W}$

$C h l b=[22.9(\mathrm{OD} 645)-4.68(\mathrm{OD} 663)] \times \mathrm{V} / 1000 \times \mathrm{W}$

$\mathrm{V}=$ volume of the extract $(\mathrm{mL})$

$\mathrm{W}=$ weight of the fresh leaf tissue $(\mathrm{g})$

Plant shoots were dried in an electric oven with drift fan at $\left(70^{\circ} \mathrm{C}\right)$ for $72 \mathrm{hrs}$ till constant dry shoot weight. The determination of total nitrogen was carried out according to micro- Kjeldahl method and the crude proteins were calculated by multiplying the total nitrogen percent by the factor of 5.7 (AOAC, 1995). At harvest, number of spikes/plant, number of grains/plant, 100-grains weight $(\mathrm{g})$ and grain yield/ plant $(\mathrm{g})$ were determined. The results were analyzed statistically using SPSS and the mean of treatments were compared using Fischer's Least Significant Differences (L.S.D) at the probability of $\mathrm{p} \leq 0.05$ (Sendecor and cochran, 1989).

Table 1: Some Physical and chemical properties of the soils used in the experiment

\begin{tabular}{|l|c|}
\hline Sand $\%$ & 69.10 \\
\hline Silt\% & 23.22 \\
\hline Clay\% & 7.68 \\
\hline Soil Texture & Sandy loam \\
\hline Organic matter\% & 0.89 \\
\hline EC $\left(\mathrm{dSm}-1\right.$ at $\left.25^{\circ} \mathrm{C}\right)$ & 0.38 \\
\hline $\mathrm{pH}$ & 7.65 \\
\hline Total nitrogen\% & 0.06 \\
\hline Available Phosphorus (mg Kg-1 soil) & 1.03 \\
\hline Soluble Potassium (mg Kg-1 soil) & 22.21 \\
\hline
\end{tabular}

Table 2: Composition of Hoagland media full strength $(100 \%)$ used in this study (Kittiwongwattana and Vuttipongchaikij, 2013)

\begin{tabular}{|l|l|}
\hline Nutrient & $\mathbf{m g L}^{-\mathbf{1}}$ \\
\hline MgSO4.7H2O & 505.5 \\
\hline KH2PO4 & 492.74 \\
\hline NH4NO3 & 136.09 \\
\hline CaNO3 & 820.45 \\
\hline H3BO3 & 2.86 \\
\hline Na2MoO4.2H2O & 0.025 \\
\hline MnSO4.H2O & 0.05 \\
\hline MnCl2.4H2O & 1.81 \\
\hline ZnCl2 & 0.11 \\
\hline FeCl3.6H2O & 0.27 \\
\hline Na2EDTA & 44.8 \\
\hline
\end{tabular}




\section{RESULTS AND DISCUSSION}

Data presented in Table (3) show that foliar application of Hoagland's solution at $1 / 4$ and 1/2 strength led to significant increases in morphological growth criteria of barley plants which included plant height, number of tillers, number of leaves, flag leaf area and shoot dry weight/plant compared to corresponding untreated plants after (100) days from sowing. Furthermore, half strength Hoagland's solution was the most effective treatment in increasing the mentioned growth parameters followed by $1 / 4$ strength treatment. These results are partially agreed with those obtained by Malakouti (2000), Ahmad et al., (2006), Ahmadikhah et al., (2010) on wheat plants and Sultana et al., (2008) on rice plants. Whereas, increasing Hoagland's solution strength to 3/4 and full strength had no significant effects. Hoagland and Arnon (1950) suggested that the presence of higher concentrations of nutrients did not increase biomass production. This result represents relatively higher nutrient utilization efficiency, as production occurred in a more diluted nutrient solution.

Elongation of cells and plant height is one of the most important acts of auxin and there is only one known natural uxin (Indol- 3-acetic acid) which has proven that this compound is made from Tryptophan amino acid (Mortazavaibak, 1998). Firouzi (2005) concluded that the reason of increase in leaf area was increase in length and width of leaves which could be because of zinc and nitrogen effect on cell dividing via auxin increasing. Shorrocks and Allowang (1988) said that copper affects nitrogen metabolism and then plant height will be increased via tryptophan and auxin producing. An increase in the shoot dry weight might be due to an increase in number of tiller and leaves, as well as leaf area leading to increase photosynthetic activity (Sultana et al., 2001).

The effect of foliar spray with Hoagland's solution on the photosynthetic pigments in the leaves of barley plants after (100) days from sowing are shown in Table (4). Hoagland's solution significantly increased chl. a, chl. $b$ and total chlorophyll recording maximum values at 1/2 strength. On the contrary, the content of such pigments were reversely changed using higher strengths of Hoagland's solution. These results agreed with those found by Mariotti et al., (1996). They observed with adding magnesium and iron to spraying fertilizer, leaf area will be increased because of iron and magnesium roles in chlorophyll production and photosynthesis increasing. Ahmad et al., (2006) observed that chlorophyll a, b, and carotenoids were increased due to complete foliar fertilizer compound and this effect may attribute to stimulation the biosynthesis of chlorophylls and delay leaf senescence.

In addition, foliar application of Hoagland's solution significantly increased total nitrogen and proteins in the leaves of barley plants after (100) days from sowing (table 4). The highest values of total nitrogen in the barley leaves were 15.61 and $15.75 \mathrm{mg} \mathrm{g}^{-1}$ leaf D.wt and for total protein were 88.97 and $89.77 \mathrm{mg} \mathrm{g}^{-1}$ leaf D.wt. respectively, were obtained by Hoagland's solution at the rates of $1 / 4$ and $1 / 2$ strength were significantly higher as compared with control (13.34 and 76.03) after 100 days from sowing. This result may be due to an increase in nitrogen content by foliar application of Hoagland's solution which consider as a building blocks in the synthesis of proteins.

Data presented in Table (5) show that foliar application of Hoagland's solution, especially at $1 / 4$ and 1/2 strength resulted in the significant increases in yield and its components (i.e., number of spikes, grains number/plant, 100-seeds weight and grain yield per plant) compared to control plants. The maximum values of yield and its components were obtained as a result of foliar spray with Hoagland's solution at $1 / 2$ strength. Whereas, increasing Hoagland's solution rates to 3/4 and full strength had no significant effects on yield and its components compared to control plants. These results are agreed with those obtained by Sultana et al., (2001) on rice plants, Kinaci and Gulmezoglu (2007) on triticale, Ahmad et al., (2006) and Ahmadikhah et al., (2010) on drum wheat. Foliar use of macro and micro elements covered all needs of wheat and had the highest 
effect on yield and its components. The increase in yield characteristics of wheat plants by using Hoagland's solution might be due to enhanced assimilation, nutrient uptake, nitrate reduction and photosynthesis, improved flow assimilates translocation transferring to grains which increased 100 grains weight and grain yield consequently (Malakouti, 2000).

Generally, such enhancement effect of foliar application with Hoagland's solution might be attributed to the combined favorable influence of their nutrients $(\mathrm{N}, \mathrm{P}, \mathrm{K}, \mathrm{Ca}, \mathrm{Mg}, \mathrm{Fe}, \mathrm{Zn}, \mathrm{Mn}, \mathrm{Mo}$, $\mathrm{B}, \mathrm{Cu}$ ) on vegetative growth of plants that reflected on an increase in growth parameters, yield and chemical constituents of plants (Glass, 1989; Jones et al., 1991). The requirement of macronutrients for plants is associated with their role in making up the bulk of the carbohydrates, proteins, and lipids of plant cells, whereas micronutrients mostly participate in the enzyme activation process of the plant (Rice, 2007). The micronutrients play roles in increasing growth and crop yield (Ahmadikhah et al., 2010) and have prominent effects on dry matter, grain yield and straw yield in crop (Emami, 2005).

Table 3: Effect of different strengths of Hoagland's solution as foliar feeding on morphological growth characteristics of barley plants after (100) days from sowing.

\begin{tabular}{|c|c|c|c|c|c|}
\hline Treatments & $\begin{array}{c}\text { Plant } \\
\text { height }(\mathbf{c m})\end{array}$ & $\begin{array}{c}\text { Number of } \\
\text { tiller/plant }\end{array}$ & $\begin{array}{c}\text { Number of } \\
\text { leaves/plant }\end{array}$ & $\begin{array}{c}\text { Flag leaf area } \\
\left(\mathbf{c m}^{\mathbf{2}} \mathbf{~ p l a n t ~}^{-1}\right)\end{array}$ & $\begin{array}{c}\text { Shoot dry wt. } \\
\left(\mathbf{g ~ p l a n t ~}^{\mathbf{1}}\right)\end{array}$ \\
\hline $\begin{array}{c}\text { Control } \\
\text { 1/4 strength } \\
\text { Hoagland's solution }\end{array}$ & 58.54 & 5.60 & 14.40 & 55.29 & 3.38 \\
\hline $\begin{array}{c}\text { 1/2 strength } \\
\text { Hoagland's solution }\end{array}$ & 64.16 & 8.80 & 17.00 & 64.01 & 4.52 \\
\hline $\begin{array}{c}\text { 3/4 strength } \\
\text { Hoagland's solution }\end{array}$ & 62.02 & 6.30 & 18.40 & 68.30 & 5.11 \\
\hline $\begin{array}{c}\text { full strength } \\
\text { Hoagland's solution }\end{array}$ & 57.80 & 5.20 & 14.50 & 60.01 & 4.45 \\
\hline \begin{tabular}{c} 
L.S.D (0.05) \\
\hline
\end{tabular} & 3.18 & 2.05 & 1.89 & 6.00 & 4.09 \\
\hline
\end{tabular}

Table 4: Effect of different strength of Hoagland's solution as foliar feeding on chlorophylls, total nitrogen and proteins content in leaves of barley plants after (100) days from sowing.

\begin{tabular}{|c|c|c|c|c|c|}
\hline Treatments & $\begin{array}{l}\text { Chlorophyll a } \\
\text { (mg g-1 leaf } \\
\text { F.wt.) }\end{array}$ & $\begin{array}{l}\text { Chlorophyll b } \\
\text { (mg g g-1 leaf } \\
\text { F.wt.) }\end{array}$ & $\begin{array}{c}\text { Total } \\
\text { Chlorophyll } \\
\left(\mathrm{mg} \mathrm{g}^{-1} \text { leaf }\right. \\
\text { F.wt. }) \\
\end{array}$ & $\begin{array}{l}\text { Total nitrogen } \\
\text { (mg g-1 leaf } \\
\text { D.wt.) }\end{array}$ & $\begin{array}{l}\text { Total proteins } \\
\text { (mg g-1 leaf } \\
\text { D.wt.) }\end{array}$ \\
\hline Control & 0.91 & 0.29 & 1.20 & 13.34 & 76.03 \\
\hline $\begin{array}{c}1 / 4 \text { strength } \\
\text { Hoagland's solution }\end{array}$ & 1.22 & 0.39 & 1.61 & 15.61 & 88.97 \\
\hline $\begin{array}{c}1 / 2 \text { strength } \\
\text { Hoagland's solution }\end{array}$ & 1.38 & 0.46 & 1.84 & 15.75 & 89.77 \\
\hline $\begin{array}{c}\text { 3/4 strength } \\
\text { Hoagland's solution }\end{array}$ & 1.13 & 0.33 & 1.46 & 15.00 & 85.50 \\
\hline $\begin{array}{c}\text { full strength } \\
\text { Hoagland's solution }\end{array}$ & 0.99 & 0.32 & 1.31 & 13.55 & 77.23 \\
\hline L.S.D (0.05) & 0.26 & 0.10 & 0.31 & 1.75 & 10.08 \\
\hline
\end{tabular}


Table 5: Effect of different strength of Hoagland's solution as foliar feeding on yield and yield components of barley plants

\begin{tabular}{|c|c|c|c|c|c|}
\hline Treatments & $\begin{array}{c}\text { Number of } \\
\text { spikes/plant }\end{array}$ & $\begin{array}{c}\text { Spike length } \\
(\mathbf{c m})\end{array}$ & $\begin{array}{c}\text { Grains } \\
\text { number/plant }\end{array}$ & $\begin{array}{c}\text { 100-seeds } \\
\text { weight (g) }\end{array}$ & $\begin{array}{c}\text { Grain yield } \\
(\mathbf{g}) / \mathbf{p l a n t}\end{array}$ \\
\hline Control & 5.20 & 11.80 & 94.66 & 5.44 & 5.16 \\
\hline $\begin{array}{c}1 / 4 \text { strength Hoagland's } \\
\text { solution }\end{array}$ & 7.60 & 13.00 & 109.66 & 5.90 & 6.48 \\
\hline $\begin{array}{c}1 / 2 \text { strength Hoagland's } \\
\text { solution }\end{array}$ & 7.80 & 14.80 & 120.33 & 6.40 & 7.71 \\
\hline $\begin{array}{c}3 / 4 \text { strength Hoagland's } \\
\text { solution }\end{array}$ & 5.60 & 13.90 & 103.66 & 5.63 & 5.86 \\
\hline $\begin{array}{c}\text { full strength Hoagland's } \\
\text { solution }\end{array}$ & 5.10 & 11.54 & 99.33 & 5.53 & 5.55 \\
\hline \begin{tabular}{c} 
L.S.D (0.05) \\
\hline
\end{tabular} & 2.13 & n.s. & 11.07 & 0.38 & 0.92 \\
\hline
\end{tabular}

\section{CONCLUSION}

From the preceding results and discussion, it can be concluded that foliar application of barley plants with Hoagland's solution at rates of $1 / 4$ and $1 / 2$ strength stimulate the growth and yield of barley and both of $3 / 4$ and full strengths were over doses.

\section{REFERENCES}

A.O.AC. (1995). "Association of Official Agricultural Chemists". Official methods of Analysis, $16^{\text {th }}$ ed. Washington D.C., USA.

Abou El-Nour, E.A.A. (2002). Can supplemented potassium foliar feeding reduce the recommended soil potassium?. Pakistan J. Biolog. Sci., 5(3), 259-262.

Ahmadikhah, A.; Narimani, H.; Rahimi, M.M.; Vaezi, B. (2010). Study on the effects of foliar spray of macro and micronutrient on yield and yield components of durum wheat. Arch. Appl. Sci. Res. 2(6), 168-176.

Ahmed, A.G.; Hassanein, M.S.; El-Gazzar, M.M. (2006). Growth and yield response of two wheat cultivars to complete foliar fertilizer compound "Dogoplus". J. Applied Sci. Research, 2(1), 20-26.

Alloway, B.J. (2008). "Zinc in Soils and Crop Nutrition". $2^{\text {nd }}$ ed., published by IZA and IFA, Brussels, Belgium and Paris, France.

Al-Obaidy, A.S.A. (2012).Estimation of impacts of rainfall on cereal production in the northern region of Iraq for the period 1992-2008. Business and Economic Research, 2(1),1-9.

Arnon, D.I. (1949). Copper enzymes in isolated chloroplasts. Polyphenoloxidase in Beta vulgaris. Plant Physiol. J., 24(1),1-5.

Emami, A. (2005). The effect of foliar absorption of macro and microelements on growth and yield of potato. M.Sc. Thesis, Agriculture Faculty. Islamic Azad University. Isfahan. Iran.

Fageria, N.K.; Barbosa, M.P.; Moreira A.;Guimaraes, C.M. (2009). Foliar fertilization of Crop Plants, Plant Nutrition J., 32(6),1044-1064.

Firouzi, M. (2005). The effect of foliar absorption of microelements on growth and yield of foliage corn. M.Sc. thesis, Agriculture College, Islamic Azad University.

Glass, A.D.M. (1989). "Plant Nutrition: An Introduction to Current Concepts". Boston: Jones and Bartlett. 
Hoagland, D.R.; Arnon, D.I. (1950). "The Water Culture Method for Growing Plants without Soil". Circ. 347. Berkeley, CA: California Agricultural Experiment Station.

Jones, I.B.; Wolf, B.; Milles, H.A. (1991). "Plant Analysis Handbook". Macro-Micro Publishing. Inc., 213 p.

Kinaci, E.; Gulmezoglu, N. (2007). Grain yield and yield components of triticale upon application of different foliar fertilizers. Interciencia. 32(9), 624-628.

Kittiwongwattana, C.; Vuttipongchaikij, S. (2013). Effects of nutrient media on vegetative growth of Lemna minor and Landoltia punctata during in vitro and ex vitro cultivation. Maejo Int. J. Sci. Technol., 7(1), 60-69.

Malakouti, M.J. (2000). "Balanced Nutrition of Wheat: An approach towards self-sufficiency and enhancement of national health". Ministry of Agriculture, Karaj, Iran. 544 p.

Mariotti, M.; Ercoli, L.; Masoni, A. (1996). Spectral properties of iron deficient corn and sunflower leaves. Remote Sensing of Environment J., 58(3), 282-288.

Marschner, H. (1995). "Mineral Nutrition of Higher Plants". Academic Press, New York.

Mortazavibak, A. (1998). Potato and its researches. Agricultural ministry press. 163 p.

Naghaii, V.; Asgharipour, M.R. (2011). Difference in drought stress responses of 20 barley genotypes with contrasting drought tolerance during grain filling. Advances in Environmental Biology, 5(9), 3042-3049.

Rice, R.W. (2007). The physiological role of minerals in the plant. In: Mineral Nutrition and Plant Disease, L.E. Datnoff, W.H. Elmer, and D.M. Huber, Eds., 9-29. St. Paul, Minnesota: The American Phytopathological Society.

Sawan, Z.M.; Hafez, S.A.; Basyony, A.E. (2001). Effect of phosphorus fertilization and foliar application of chelated zinc and calcium on seed, protein and oil yields and oil properties of cotton. J. Agric. Sci., 136, 191-198.

Shorrocks, V.M.; Alloway, B.J. (1988). Copper in plant, animal and human nutrition. International Copper Research Association, 99 p.

Snedecor, G.W.; Cochran, W.G. (1989). "Statistical Methods". 7th ed. The Iowa State University Press U.S.A, pp.215-298.

Stickler, F.; Pauli, A.W. (1961). Influence of date of planting on yield and yield components of grain sorghum. Agronomy J. 53, 22-23.

Sultana, N.; bIkeda, T.; Kashem, M.A. (2001). Effect of foliar spray of nutrient solutions on photosynthesis, dry matter accumulation and yield in seawater-stressed rice. J. Envir. and Exper. Bota., 46(20), 129-140. 